\title{
Contratos Administrativos
}

\section{Licitações - Exclusões - Constitucionalidade do Decreto 64.345/69}

\author{
Walmor Franke \\ Magistrado aposentado da Justiça do \\ Estado do Rio Grande do Sul
}

\section{SUMARIO:}

1 - A utilidade pública como princípio informativo dos contratos administrativos. 2 - Indeterminação do conceito de utilidade pública. Competência da Administração para defini-la nos casos concretos. 3 - A escolha do co-contratante pela Administração. 4 - O principio da liberdade de escolha e suas limitações. 5 - Ajustes diretos e licitações públicas. 6 - Inexistência de direito subjetivo dos particulares a prestar serviços ao Estado. 7 Situaçōes subjetivas dos interessados no procedimento licitatório. 8 - A licitação como invitatio ad offerendum. 9 - Igualdade de tratamento diante do e no procedimento da licitação. O momento da habilitação preliminar. 10 - Valor do caderno de encargos e do edital da licitação. 11 - Competência da Administração para estabelecer os requisitos de acesso ao procedimento licitatório. 12 - 0 "avviso d'asta" no direito italiano. 13 - 0 instituto da "egréation préalable", na Bélgica. 14 - Inserção dos requisitos de admissão nos cadernos de encargos, na França. 15 - Função do "pliego de condiciones", no direito hispano-americano. 16 Exclusão de licitantes por motivos de nacionalidade. 17 - Obstáculos à exclusão, por tal motivo, nos paises do Mercado Comum Europeu. 18 - Disciplinamento das licitações no direito pátrio. Decreto-lei n. ${ }^{\circ}$ 200, de 1967. 19 - Exclusão das licitações por motivos de moralidade administrativa. 20 - Competência implicita da Administração para definir tais motivos. 21 - Exclusões estabelecidas por via regulamentar, com fundamento em interesse público relevante. Legitimidade do procedimento. 22 - Disposições do Decreto n. ${ }^{\circ} 64.345$, de 1969 , concernentes ao controle acionário de empresas de serviços de engenharia. 23 - Seu caráter regulamentar. 24 - Finalidade do Decreto: proteger a enge- 
nharia nacional. 25 - Contrataçăo administrativa de serviços de engenharia mediante ajuste direto. Ausência de ofensa a direito subjetivo individual. 26 - Argüição de inconstitucionalidade do Decreto n. ${ }^{\circ}$ 64.345. Razões invocadas. 27 - Constitucionalidade do Decreto-lei n. ${ }^{\circ} 200$, de 1967 , na regulação dos contratos administrativos. 28 - Técnica defeituosa do Decreto n. ${ }^{\circ} 64.345$ na definição de "empresa nacional". Ausência de intençăo de legislar. Sentido exato da expressão usada. 29 - Discriminações constantes do Decreto, consideradas em face do principio constitucional de isonomia. 30 - Conceito de igualdade perante a lel. 31 Grupos de empresas objeto de discriminação. 32 - Condições de aplicação do art. 153 da Constituição Federal às sociedades em geral. Seus limites. 33 - Tratamento desigual de brasileiros residentes dentro e fora do país. Casos em que se justifica. 34 Desigualdade de tratamento de estrangeiros residentes no exterior. Não constitui ofensa à Constituição. 35 - Distinções entre brasileiros e estrangeiros residentes no país. Possibilidade jurídica da discriminação em lei ordinária. Exemplos. Presunção em favor da legitimidade do ato discriminatório. Incumbe ao estrangeiro o ônus da prova da ilicitude do ato. 36 - Desigualdade de tratamento dos estrangeiros, no direito francês. 37 - Discriminações existentes no direito norte-americano e no de outros países. 38 - Constitucionalidade do Decreto n. ${ }^{\circ} 64.345 / 69$.

\section{A utilidade pública como princípio informativo dos contratos administrativos}

1. No exercício da missão, que lhe cabe, de realizar o interesse coletivo, a Administração do Estado (União, Estadosmembros, Municípios etc.) precisa utilizar bens e serviços, assim como executar obras de diferentes espécies denominadas "obras públicas".

A obtenção desses bens e serviços ou a realização dessas obras - quando a sua produção não se faz, por meios técnicos adequados, dentro do âmbito do poder administrativo - será alcançada, externamente, no mercado, mediante contratos que a Administração celebra com terceiros, via regra, particulares, vale dizer, pessoas físicas ou jurídicas integrantes da categoria geral dos "administrados".

Os contratos realizados pela Administração para a aquisição de bens, a obtenção de serviços e a construção de obras, celebram-se, geralmente, não pelas formas comuns do direito civil ou comercial, mas com observância de certas formalidades, estabelecidas em leis e regulamentos, perfazendo aquele tipo contratual que, na técnica do direito moderno, se denomina "contrato administrativo". 
Abstraindo das discussões doutrinárias em torno da admissibilidade, ou não, dessa figura contratual no moderno direito administrativo e reconhecendo-lhe, desde logo, justificado lugar no quadro desse ramo jurídico, diremos que a existência do contrato administrativo decorre, substancialmente, do próprio conceito de administração pública, que é, por sua natureza, atividade vinculada à realização, de fins de utilidade pública ou de interesse coletivo. ${ }^{1}$

O motivo de utilidade pública, como critério diferenciador do contrato administrativo, tem sido invocado largamente pela doutrina. ${ }^{2} \mathrm{E}$ como o interesse coletivo, por sua própria natureza, predomina sobre o particular, esse predomínio também se verifica, sem sombra de dúvida, nos contratos de obras e serviços que a Administração realiza com pessoas privadas. ${ }^{3}$

\section{Indeterminação do conceito de utilidade pública e competência para sua definição}

2. A idéia correspondente à expressão "utilidade pública" ou "interesse coletivo" não tem conteúdo certo, fixo ou definido. Trata-se de conceito com grande margem de indeterminação e que, por isso mesmo, pode variar de acordo com a época e as circunstâncias. Incumbe à Administração, quando for o caso, apreciar a "utilidade pública" ou "interesse coletivo" de uma medida regulamentar ou de um ato ou contrato administrativo, de conformidade com juízos de valor baseados em critérios atuais, hauridos do exame da realidade social ou das condições de vida de determinado momento histórico.

Um século atrás, já atentara PRADIER-FODÈRE para esse aspecto da mutação das circunstâncias dentro das quais a Administração exerce a sua atividade e às quais deve afeiçoar-se para satisfação das exigências do bem comum.

1 - Cf. RUY CIRNE LIMA, Contratos Administrativos e Atos de Comércio, in Rev. de Dir. Adm., vol 32 , pag. 23 e segs.

2- "É exato, acentua WALINE, que a jurisprudéncia conhece a certos contratos concluidos por uma pessoa de direito público, aos assim denominados contratos administrativos, efeitos que săo os indicados por JÉZE e que diferem dos efeitos dos contratos civis. Por que motivo, porém? É válido esse motivo?". E WALINE responde, afirmativamente: "O motivo é o indicado por JÉZE; a utilidade pública" (Précis de Droit Administratif Paris 1960, pág. 21).

3 - A norma básica, escreve J. CRETELLA JUNIOR, que informa todo o campo do direito público é também inspiradora dos contratos administrativos: "o interesse público está acima do interesse particular" (Tratado de Direito Administrativo, vol. III, pág. 65). E GUIMARÃES MENEGALE adverte: "A tendência dos publicistas é conferir primazia ao interesse público ou ao interesse administrativo nas relaçǒes do Estado com 0 indivíduo... Em negócio jurídico em que sejam sujeitos a administraçăo e um particular, a relação se considera de direito público pela preponderância do interesse coletivo" ("Con-

tratos Administrativos" in Repertório Enciclopédico do Direito Brasileiro, vol. 12, pág. 291). 
"A administração ativa, dizia ele, deve levar em conta os tempos, os lugares e as circunstâncias que podem modificar ao infinito a intensidade das necessidades e a oportunidade de sua satisfação. Sua iniciativa deve ser muito ampla. É, com efeito, a consciência dos povos, traduzida nos costumes e na legislação, quem lança a base dos princípios gerais; mas as inumeráveis eventualidades que podem apresentar-se na aplicação desses princípios, devem encontrar, no poder incumbido de pôlos em prática, uma completa independência de ação" (Précis de Droit Administratif, Paris, 1872, pág. 17).

MARCELLO CAETANO aponta para o fato de que a variação no conceito de "interesse público" é de molde a condicio. nar a atividade administrativa através do tempo.

"O interesse público, afirma o ilustre escritor, é, em relação à Administração, uma idéia transcendente, que não depende dela, pelo contrário, exerce sobre ela o seu império. Desde que a coletividade exija, por virtude de transformações econômicas, técnicas, morais ou simplesmente políticas, que os serviços administrativos tomem outro rumo, o caráter instrumental destes, como meios diretos ou indiretos de satisfação das necessidades coletivas, impõe a adaptação...

Desse modo, é "à Administração e aos órgãos de soberania que compete definir em cada momento e em cada lugar as expressões corretas do interesse público, definição que se opera por atos jurídicos de autoridade - sejam leis, regulamentos ou atos administrativos" (Manual de Direito Administrativo, 7a. ed., Lisboa, 1965, págs. 305-306).

\section{A escolha do co-contratante pela Administração}

3. Os serviços, de que o Estado necessita, bem como as obras, cuja execução o interesse coletivo reclama, podem ser realizados diretamente pela Administração, valendo-se ela dos seus recursos técnicos e do seu próprio pessoal, sem a cooperação da indústria privada. Quando, porém, isto não seja possível ou não convenha, a Administração realiza, comumente, os seus fins, mediante contratos celebrados com particulares.

Nesse caso, incumbe à Administração escolher o seu cocontratante. 


\section{O princípio de livre escolha e suas limitações}

4. Em linha de princípio, a regra que vige para a Administração é a da liberdade de escolha. Para que a escolha não seja livre, faz-se mister regulamentação jurídica que disponha de outro modo.

"Quel que soit - diz PEQUIGNOT - notre désir de faire apparaitre l'autonomie du droit administratif, nous sommes obligé de reconnaitre qu'en droit administratif, comme en droit privé, le principe c'est que l'Administration choisit librement son cocontratant. La multiplicité des textes qui prévoient l'adjudication dans une foule d'hypotèses déterminées, si nombreuses qu'elles soient, prouve qu'un texte est nécessaire pour l'imposer" (Théorie Générale du Contrat Administratif, Paris, 1945, pág. 39).

“En droit positif, afirma BENOIT, le principe générale est celui de la liberté de choix de son cocontractant par l'Administration: l'autorité administrative compétent choisit librement le particulier avec lequel elle entend concluire un contrat" (Le Droit Administratif Français, Paris, 1968, pág. 608).

O princípio da liberdade de escolha, no entanto, está sujeito, em regra, nos diversos sistemas jurídicos, a maiores ou menores restrições, ditadas não só pelo intuito de assegurar a insuspeição, a moralidade e imparcialidade dos órgãos administrativos na eleição do co-contratante, senão também por motivos de outra natureza, inspirados na idéia de garantir ao Estado o melhor resultado, direto ou indireto, possível, na realização do negócio visado.

Assim, depara-se-nos, comumente, duplo regime na contratação de bens, serviços e obras por parte da Administração com particulares:
a) o da livre escolha; e
b) o da licitação pública.

\section{Ajustes diretos e licitações públicas}

5. Quando a Administração tem a liberdade de escolher o seu co-contratante, o negócio jurídico, destinado a proporcionar-lhe os fornecimentos, serviços e obras de que necessita, faz-se mediante ajuste direto. A Administração elege discricio- 
nariamente a outra parte contratante, nada impedindo que, no respectivo processo, realize prévia consulta, quanto a preços e outros elementos, a maior ou menor número de interessados na contratação (Cf. JOSÉ CRETELLA JUNIOR, Tratado de Direito Administrativo, 1a. ed., 1967, vol. III, pág. 106; MARCELLO CAETANO, Manual de Direito Administrativo, 7a. ed., pág. 312).

É evidente que no regime da livre escolha não há que falar em direito subjetivo de quem quer que seja a prestar serviços ao Estado.

\section{Inexistência de direito subjetivo a prestar serviços ao Estado}

6. O direito dos particulares de figurarem, como parte, em contratos administrativos, também inexiste, em princípio, nas licitações públicas, não só em razão do juízo de conveniência atribuído à Administração de escolher a proposta de um deles como a mais vantajosa, senão também pela faculdade que a Administração possui de recusar as propostas na sua totalidade, revogando a licitação em qualquer momento de sua execução processual.

"La busqueda del contratante o contratista, adverte BARTOLOME A. FIORINI, continúa como proceso unilateral para la administración pública, pues esta podrá dejarlo sin efecto o suspender el processo sin adquirir ninguna responsabilidad" (Manual de Derecho Administrativo, vol. II, pág. 427).

"Até a assinatura do contrato, a administração não se acha obrigada para com os concorrentes. Poderá não aceitar nenhuma das propostas, anular ou suspender a concorrência, sem que de seu ato decorra qualquer espécie de responsabilidade civil" (JOSÉ CRETELLA JUNIOR, op cit. vol. III pág. 113).

\section{Situações subjetivas no processo licitatório}

7. O direito dos particulares pode apresentar-se, na licitação pública, sob outros aspectos, vinculados a diversos momentos do procedimento licitatório. No desdobramento da licitação, os interessados passam, em verdade, por diferentes situações subjetivas, suscetíveis de gerarem pretensões jurídicas, ligadas ao interesse de realizar, afinal, o contrato com a Administração. Essas pretensões são desde a admissão à licitação até a assinatura do contrato. 


\section{A licitação como convite a ofertar}

8. No estudo da licitação pública, o direito de acesso do particular ao procedimento licitatório apresenta-se com o caráter de uma questão preliminar de suma importância, que envolve, ao mesmo tempo, o exame do direito que assiste à Administração de recusar, desde logo, a admissão do interessado ao processo.

A licitação pública, inclusive no direito pátrio, é um procedimento genérico que assume várias modalidades de chamamento de particulares à celebração de contratos administrativos. SAYAGUÉS LASO assim a define: "La licitación es un procedimiento relativo al modo de celebrarse determinados contratos, cuya finalidad es la determinación de la persona que ofrece a la Administración condiciones más ventajosas; consiste en una invitación a los interessados para que, sujetandose a las bases preparadas (pliego de condiciones), formulen propuestas, de las cuales la Administración seleciona y acepta la más ventajosa (adjudicación), con lo que el contrato queda perfeccionado; y todo el procedimiento se inspira para alcanzar la finalidad buscada, en estos principios: igualdad de todos los licitantes ante la administración y cumplimiento estricto de las cláusulas del pliego de condiciones" (La Licitación Pública, 1940, pág. 53, apud HELY LOPES MEIRELLES, Direito Administrativo Brasileiro, 2.` ed., pág. 251). analisa:

BARTOLOME A. FIORINI, tratando do instituto, assim o

"El Ilamado a la licitación es el acto administrativo de relevancia juridica para los concurrentes a la oferência...

"Este Ilmado de demanda es la ejecución con caracter público del acto o pliego reglamentario denominado licitación.

"La licitación preséntase así como un procedimiento, donde la administración pública elegirá o selecionará al particular contratante, por tratarse de un procedimiento donde está afectado el interés público. Las disposiciones que la rigen son normas substanciales para la formación del proceso administrativo" (Cf. op. cit., pág. 433).

E mais adiante acentua:

"La correción y legitimidad del proceso licitario se sustenta en: a) indutibilidad de la documentación presupuestal; 
b) cumplimiento estrito de la publicidad; c) tratamiento igualitario para todos los concurrentes en la licitación. Estos disposiciones hacen a la unidad de todo el procedimiento concursal y se sustentam en el interés público" (op. cit., pág. 434).

Igualdade de tratamento diante do e no procedimento licitatório

9. Os autores, de um modo geral, sublinham que a validade da licitação está condicionada pela igualdade de tratamento dispensada pela Administração a todos os interessados.

Como a licitação, porém, é um procedimento que se desdobra em diversas fases, o princípio de igualdade de tratamento, . a que se refere a doutrina, pode e deve ser encarado sob duplo aspecto:

a) tratamento igualitário dos interessados no que respeita ao acesso à licitação ou, em outros termos, na sua admissão ao procedimento licitatório:

b) igual tratamento dos interessados, já na sua condição de licitantes, nas diferentes fases do procedimento licitatório, até 0 ato da adjudicação.

Esta distinção cabe especialmente no direito brasileiro, quando se trata da modalidade de licitação, definida no art. 127 da Lei $n .^{\circ} 200$, de 25.2.67, sob o nome de "concorrência", que se caracteriza pela existência obrigatória de uma fase inicial, designada como de "habilitação preliminar destinada a comprovar a plena qualificação dos interessados para a realização do fornecimento ou execução da obra ou serviço programados" (art. $127, \S 2 .^{\circ}$ ).

A qualificação dos interessados nessa habilitação preliminar implica o exame do seu direito de acesso à licitação, vedadadas, por força do princípio de isonomia, discriminações injustas entre os que ostentam iguais predicados ou que se encontrem nas mesmas condições.

\section{Valor do caderno de encargos e do edital da licitação}

10. Os requisitos que os interessados devem preencher para serem admitidos à licitação concorrencial constarão, necessariamente, do edital da concorrência, tal como figuram, por exem- 
plo, no direito português, nos cadernos de encargos, conjunto de cláusulas e condições redigidas unilateralmente pela Adiministração para definir em que termos esta se encontra disposta a contratar (Cf. MARCELLO CAETANO, op. cit., pág. 315); ou nos pliegos de condiciones, do direito espanhol ou hispano-americano, que contêm "normas generales... estabelecidas por el Poder Ejecutivo o las autoridares directivas de los organismos descentralizados autarquicamente" (BARTOLOME A. FIORINI, op. cit., pág. 426); ou no avviso d'asta do direito italiano, que "deve contenere le indicazioni relative al giorno, al luogo ed alle modalità della gara, nonchè quelle concernenti i requisiti che le persone e le ditte devono presentare per esservi ammesse" (ZANOBINI, Corso di Diritto Amministrativo, 3." ed., vol. III, pág. 329); ou, finalmente, nos cahiers des charges, do direito francês, que "énumérent, de ces divers points de vue, les conditions que doivent remplir les candidats" (GEORGES PEQUIGNOT, op. cit., pág. 215).

Os requisitos de admissão devem constar desses documentos que constituem a base do processo da concorrência. Quem, entretanto, poderá definir esses requisitos e dentro de que limites poderão ser eles definidos, desde que se admita o princípio da liberdade de acesso, em igualdade de condições, dos candidatos à concorrência (estudada pelos autores franceses sob o título de adjudication)?

\section{Competência da Administração para fixar os requisitos de acesso à licitação}

11. Segundo MARCELLO CAETANO, no direito português, "o Supremo Tribunal Administrativo e o Tribunal de Contas definiram a doutrina de que a Administração tem plena liberdade de escolha da pessoa com quem há de contratar - escolha que se faz no ato da adjudicação; mas que não tem o poder discricionário de recusar a admissão ao concurso de quem se encontre nas condições legais e regulamentares de concorrer" (op. cit., pág. 317).

Esta doutrina se refere a condições regulamentares de concorrer, o que induz a conclusão de que tais condições, na opinião dos tribunais lusitanos, também podem ser estabelecidas em regulamento que, na definição de MARCELLO CAETANO, é função do Poder Executivo, que "só pode estatuir na medida em que a lei lhe consinta: - dentro dos limites por ela marca- 
dos, ou para execução de suas normas, ou sobre as matérias por ela abandonadas" " (Cf. op. cit., pág. 84).

\section{O "avviso d'asta" no direito italiano}

12. Consoante se lê em ZANOBINI (Corso di Diritto Amministrativo, vol. IV, pág. 329), na Itália, o Regulamento de Contabilidade, no seu art. 68, estabelece que "I" amministrazione ha piena e insindacabile facoltà di escludere dall'asta qualsiasi concorrente, senza che l'escluso possa reclamare alcuna indennità nè pretendere di conoscere le ragioni dell'esclusione".

Esclarece ZANOBINI que, tratando-se de disposição regulamentar, foi a sua legalidade questionada perante os tribunais, mas, a seu ver, o direito de exclusão, por parte da Administração, existe quando a norma regulamentar consta do edital (avviso d'asta) da concorrência.

"Nella giurisprudenza meno recente - escreve o jurista italiano, referindo-se ao art. 68 do Reg. de Contabilidade - fu discurso intorno alla legitimità di questa disposizione, sostenendosi talora che dall'avviso d'asta nascerebbe un diritto soggetivo che non potrebbe essere escluso da una norma regolamentare. Tale tese sembra infondata, essendo la norma riprodotta o richiamata negli stesse avvisi di asta. Sulla questione, v. L. Forti, La formazione dei contratti cit., pg. 21" (GUIDO ZANOBINI, op. cit., pág. 329 , nota 10 ).

A importância atribuída pela doutrina italiana ao avviso d'asta (edital de licitação) como peça básica da concorrência, leva a concluir que a não satisfação dos requisitos regulamentares enumerados neste avviso cria para a Administração o direito de excluir o candidato.

\section{A "agréation préalable", na Bélgica}

13. Na Bélgica, a Administração dispõe de um serviço de "aceitação prévia" (agréation préalable) dos empresários de serviços públicos.

"L'idée - escreve FLAMME - d'une sélection préalable des entreprises aptes à mener à la bonne fin les travaux publics est née à la suite de longues discussions et échanges de vues qui se sont poursuivis bien avant la dernière guerre 
mondiale au sein des associations profissionnelles et qui étaient centrées sur la double préoccupation de metre les entrepreneurs sérieux à l'abri de confrères fantasistes, incorrets ou incapables, en même temps que d'assurer à l'Administration les garanties optima de bonne exécutions des travauxs qu'elle entreprend.

"Ainsi fut lancée la formule de l'agréation préalable, qui fuit mise en pratique dejà sous l'occupation par un arrêté des secretaires généraux du 22 février 1941, mais dont I' organisation fut laissée à l'Administration. Malgré les innombrables embûches qui lui furent tendues durant la guerre - dans le but, on le devine, de faire servir l' "agréation" à des fins étrangères, voire opposées aux vues de ses initiateurs - la Comission d'agréation agréa jusqu'à fin 1946 près d'un millier de firmes, tout écartant les entreprises étrangères ou camouflées et en se refusant à tenir compte de références de travaux éxécutés pour l'occupant, de manière à maintenir dans leurs position réelle d' avant guerre des entreprises qui espéraient tirer avantage sans vergogne de la collaboration qu'elles avaient apportée à l'ennemie" (FLAMME, Traité Théorique et Pratique des Marchés Publics, Bruxelas, 1969, vol. I, pág. 326).

A resolução (arrêté) dos secretários gerais que, em 1941, instituiu, na Bélgica, o sistema da aceitação prévia (agréation préalabre), expirou em fevereiro de 1946, tendo sido prorrogada, até fim de 1946, por nova resolução do governo.

Enfim, aos 3 de fevereiro de 1947, sobreveio uma lei (arrêté-loi) que, no dizer de FLAMME, "reproduziu com bastante fidelidade, mas em os completando e aperfeiçoando, os princípios básicos da antiga legislação" (Cf. op. cit., pág. 327).

Entre os requisitos de aptidão para a "agréation préalable", a lei de 1947 manteve o da posse da nacionalidade belga dos empresários ou, tratando-se de sociedade, o de que, pelo menos, duas terças-partes do seu capital fossem belgas.

“L'aptitude requise par l'arrêté-loi découle de la réunion de certaines conditions, telles que l'inscription aux registre du commerce, la possession de la nationalité belge (s'il s' agit d'une societé, il faut que le deux tiers du capital au moins soient belges), l'absence d'exclusion des marchés et adjudication de l'Etat..." (FLAMME, op. cit., vol. I, pág. 328). 
A exigência da posse da nacionalidade belga pode ser derrogada, .quando se trata de serviços de natureza particular, cuja execução é entregue a firmas estrangeiras especializadas (FLAMME, op. cit., pág. 340).

\section{Menção dos requisitos de admissão nos "cahiers de charges", na França}

14. Segundo ANDRÉ DE LAUBADĖRE, no direito francês, a liberdade de acesso à licitação é o reflexo de certas idéias mais gerais dominantes no século $\mathrm{XIX}$, como a do liberalismo econômico fundado sobre a livre concorrência e o da igualdade dos indivíduos perante os serviços públicos.

Analisando o conteúdo e a extensão do princípio de liberdade de acesso à concorrência aberta (adjudication ouverte), expõe LAUBADÉRE:

"Ce principe signifie que tous les entrepreneurs ou fournisseurs appartenant à la profession dont reléve le marché soumis à une adjudication doivent être admis à participer à celleci en déposant des soumissions...

"Dans sa forme absolue le principe de la liberté d'accès devrait donc impliquer qu'acune catégorie des particuliers se rettachant à la profession intéressée n'est exclue des opérations d'adjudication ni ne peut eu être exclue par une mesure générale ou spéciale émanant de l'administration qualifiée pour ouvrir une adjudication.

"Ce forme absolue du principe n'a cependant jamais été retenue: l'accès à l'adjudication a toujours comporté la possibilité de certains restrictions... Sans doute, dans l'adjudication publique ouverte, le principe demeure celui du libre accès; le décret de 6 avril 1942, article 11, dispose même que "I'adjudication publique ouverte comporte... une concurrence illimitée"; mais on va voir que cette dernière expression ne doit pas être prise au pied de la lettre et que, dans ce type même d'adjudication, la libre concurrence comporte la possibilité d'importants limitations" (Traité Théorique et Pratique des Contrats Administratifs, tomo I, Paris, 1956, n. ${ }^{\circ} 272$, págs. 268-269). 
Estas limitações sofridas pelo princípio de liberdade de acesso são de origens e fundamentos diversos. Constam elas de disposições inscritas nos "cadernos de encargos" (cahiers des charges) das concorrências, redigidas unilateralmente pela Administração e que fixam as condições que a mesma estabelece para o procedimento licitatório.

Sublinhando a importância do "caderno de encargos", escreve PEQUIGNOT:

"L'élément le plus remarquable du marché de travaux publics, c'est le cahier des charges, espécialment le cahier des clauses et conditions générales. Toutes les Administrations ont inséré dans de grands instruments qu'elles reprennent pour faire la lois de chacun de leurs contrats les règles qu'une longue experience leur a révélé être les meilleures. Ces régles sont proposées (ne devrait-on pas dire imposées?) aux entrepreneurs qui, s'ils veulent contracter, sont obligés de les acepter sans être admis à les discuter. Les cahiers des charges des grands services publics sont fréquemment arrêtés par décret et l'Administration n'est pas libre d'y déroger ou ne peut parfois le faire, qu'en suivant une procédure rigoureuse" (op. cit., pág. 42).

As restrições impostas ao princípio de livre acesso figurarão, obrigatoriamente, no direito administrativo francês, dos "cahiers des charges". Mostrando a extensão das disposições restritivas que tais "cadernos" podem conter, esclarece LAUBADËRE:

"Le cahier des charges de l'adjudication peut imposer des conditions aux soumissions. Ces conditions peuvent toujours être édictées lorsqu'elles n'aboutissent pas à exclure des catégories de personnes mais seulement à exiger des candidats

qu'ils se plient à certaines obligations. Mais ils peuvent également être regulières lorsqu'elles aboutissent à de véritables exclusions de catégories...

"L'idée générale est que peuvent être admises les conditions imposées dans l'intérêt du service contractant ou de la meilleure réalisation du marché et n'aboutissant pas à exclure un nombre trop important de concurrents éventuels. 
"Mais la loi peut, elle-même, prévoir des conditions dépassant cette formule, étrangères à l'intérêt direct du service ou du marché, par exemple, comme on va le voir, des conditions inspirées des considérations sociales, fiscales etc." (op. cit., n. ${ }^{\circ}$ 273).

\section{Função do "pliego de condiciones" no direito hispano-americano}

15. O "pliego de condiciones", do direito espanhol ou hispano-americano, corresponde aos "quinterni d'oneri" ou "capitulati", do direito italiano, ou aos "cahier des charges", do direito francês.

SAYAGUÉS LASO, referindo-se ao "pliego de condiciones", informa que também nele se contêm, muitas vezes, discriminações entre inteiras categorias de pretendentes à licitação.

"El pliego de condiciones, escreve o ilustre autor, puede definir-se como el conjunto de cláusulas redactadas por la administración, especificando el suministro, obra o servicio que se licita, estabeleciendo las condiciones del contrato a celebrarse y determinando el trámite a seguir en el procedimiento de licitación.

"Por su contenido algunos autores lo han denominado, con acierto, la "ley del contrato". En realidad, es algo más que eso, pues incluye normas que se refieren al procedimiento a seguir...

"Siendo la igualdad de los participantes uno de los principios básicos de la licitación, los pliegos deben establecer reglas generales e impersonales, que mantengan fielmente aquélla. Esto no excluye que puedan incluirse cláusulas estableciendo cierta preferencia en favor de determinadas categorias de licitantes. Ese principio ha sido aplicado muchas veces en nuestro país, estableciendo diversas preferencias dentro de límites razonables".

E, em nota, SAYAGUÉS LASO exemplifica, referindo-se ao direito uruguaio: "preferencia en favor de firmas nacionales $y$ determinación de cuales se considerarian tales" (Tratado de De. recho Administrativo, 1963, vol. I, págs. 560-561). 


\section{Exclusão de licitantes em razão da nacionalidade}

16. A exclusão do procedimento licitatório pode, conseguintemente, atingir interessados individuais que não preencham os requisitos exigidos, como, até mesmo, por motivos fundados, inteiras categorias de pessoas, consideradas inaptas para a licitação. Além disso, como acentua LAUBADĖRE, o motivo da exclusão tanto pode fundar-se no interesse direto da boa execução da obra ou do serviço, como em considerações de ordem social, fiscal etc., que transcendem à noção estrita de serviço público.

Entre as considerações de ordem social, estranhas ao interesse direto do serviço, e que levam à exclusão de verdadeiras categorias da licitação, inclui-se, indubitavelmente, a nacionalidade estrangeira dos interessados ou, tratando-se de sociedade, o controle acionário desta por estrangeiros (Cf. FLAMME, op. cit., pág. 328).

Escrevendo nas primeiras décadas deste século, já acentuava JËZE que "la concurrence ne doit être illimitée: il ne faut admettre à faire des offres que les personnes jouissant d'une pleine capacité juridique, les sociétés, valablement constituées, honorables, solvables, capables d'executer le contrat et ayant des intentions sérieuses de contracter" (Les Principes Généraux du Droit Administratif, 3a. ed., I, pág. 85).

Mas, além desses requisitos que entendem com a boa execução do serviço ou da obra, já citava JĖZE a nacionalidade dos interessados como motivo determinante de admissão ou exclusão. "Parfois, diz o ilustre escritor, la nationalité française est exigée des concurrents sauf dispense ministérielle. Cette condition se trouve pour les adjudications de travaux ou fournitures militaires" (op. et loc. cit.) ${ }^{4}$

O critério da nacionalidade, como motivo de exclusão de verdadeiras categorias de pessoas, quais sejam as estrangeiras, não ficou adstrito, no direito francês, às concorrências para a execução de obras militares, mas, por força da jurisprudên-

\footnotetext{
4 - Como fonte desse motivo de exclusão, cita JèZE as Instruçōes sobre licitaçőes dos Ministérios Militares (Cf. Les Principes Généraux du Droit Administratif, 3.a ed., I, pág. 85, nota 1). Mais adiante, depois de observar que "le cahier des clauses et conditions générales est complété par une ou plusieurs instructions ministérielles" e que "le cahier de C. et C.G. et les instructions ministérielles forment un tout", adverte JÈZE que tanto o caderno de condiçőes gerais de obras (travaux), como o de fornecimentos (fournitures), fazem remissăo a essas Instruçōes, de onde constam "les conditions à remplir pour être admis à concourir aux adjudications" (op. cit., I, págs. 149-151).
} 
cia do Conselho de Estado, passou a vigorar como motivo geral de exclusão em qualquer tipo de licitação, ainda mesmo quandơ não houvesse um texto expresso de lei a dispor nesse sentido. Apenas, no caso Franel, julgado em 2 de fevereiro de 1938, o Conselho de Estado exigiu, para a legitimidade da exclusão, que, pelo menos, a exclusão por motivo de nacionalidade constasse do "cahier des charges". É o que nos informa LAUBADĖRE, quando, a propósito, escreve:

"L'accés aux adjudications peut être réservé aux candidats de nationalité française.

"Il ne s'agit plus ici, on le voit, d'une limitation de la libre concurrence justifiée par une meilleure exécution du marché, mais soit par des considérations particuliers à certains catégories de marchés, soit même par une consideration générale de protectionnisme national. Cependant, en l'absence même de texte, la jurisprudence, après avoir condanné les clauses excluant les étrangers (Cours des comptes, 3 décembre 1906, Montceau-les-Mines, cité par QUANCARD, op. cit., p. 135) a reconnu leur liceité, non seulement dans les marchés mettant en jeu un intérêt politique ou militaire, mais d'une manière générale dans n'importe quelle catégorie de marchés: C.E. 9 novembre 1934, Smith, p. 1040; 29 mai 1936, Société de L'Ouest africain, p. 620. Elle est actuellment stipulée dans divers C.C.G., non seulement militaires (C.C.G. travaux guerre, art. 11; marine, art. 2; fournitures militaires, art. 21), mais également civils (par ex., travaux P.T.T., art. 2; Ville de Paris, art. 2)" (LAUBADÈRE, op. cit., I, pág. 273).

E em nota, ao pé da pág. 273 de sua obra, tomo I, cita LAUBADÈRE a decisão do Conselho de Estado, de 2.2.38, no caso Franel, em que foi julgado que "a comissão de adjudicação não pode excluir um candidato estrangeiro pela só razão de sua nacionalidade, se a condição de nacionalidade francesa não foi prevista pela lei ou pelo "cahier des charges". A inserção da cláusula de exclusão no "cahier des charges", é, pois, suficiente para eliminar o interessado estrangeiro. ${ }^{5}$

5 - No mesmo sentido CHARLES GEORGIN, Cours de Droit Administratif, 18a, ed., Paris, 1952, pág. 248: "Aux conditions d'admission fixóes par des dispositions d'ensemble, le cahier des charges d'une entreprise déterminée peut d'ailleurs ajouter des conditons particulières à cette entreprise. II peut stipuler, par exemple, l'obligation, pour les concurrentes, d'être de nationalité française, lorsque la loi ne l'exige pas elle-méme..." 


\section{Obstáculos à exclusão por motivo de nacionalidade nos países do Mercado Comum Europeu}

17. A exclusão por motivo de nacionalidade encontra, atualmente, obstáculo no regime do Mercado Comum Europeu, quando ali se trata de aplicar a cláusula excludente a súdito de países integrantes desse Mercado.

Além da Bélgica e da França, essa cláusula, pelo que se deduz de FLAMME, também é adotada na Itália, no "registro nacional dos empresários de obras públicas". "Le Traité de Rome, adverte FLAMME, ne fait nul obstacle au mantien par la Belgique et Italie des leurs "listes" officielles d'entrepreneurs agrées, à condition bien entendu que ces deux pays suppriment à l'ègard de leur partenaires toutes les discriminations fondées sur la nationalité" (op. cit., vol. I, n. 255, pág. 363).

Também, na França, segundo WALINE, "la condition de nationalité française ne peut même être exigée, du fait du Traité de Rome" (Précis de Droit Administratif, pág. 406, nota 1).

Se os países sujeitos ao Tratado de Roma já não mais podem discriminar, no Mercado Comum Europeu, por motivo de nacionalidade, tal participação, ao que parece, segundo FLAMME, não impede que a cláusula excludente seja aplicada a nacionais de outros Estado, estranhos àquele Tratado.

\section{Disciplinamento das licitações no direito pátrio: Decreto-lei $n .^{\circ}$ 200, de 1967}

18. No direito pátrio, as licitações para compras, obras e serviços encontram-se, hoje, reguladas pelo Decreto-lei $n .^{\circ} 200$, de 25.2 .67 (arts. 125 a 144).

Em face das novas regras estabelecidas, a propósito, nesse Decreto-lei, devem considerar-se "revogadas as disposições do Código de Contabilidade Pública da União e de seu Regulamento, que regiam anteriormente as concorrências e tomadas de preços, assim como as demais normas incompativeis com a atual disciplina do instituto" (Cf. HELY LOPES. MEIRELLES, Licitações e Contratos Administrativos, in Rev. de Dir. Administrativo, vol. 105, pág. 15). 
Com exceção dos casos ressalvados no $\S 2 .^{\circ}$ do art. 126 do Decreto-lei, as compras, obras e serviços, no regime desse diploma, "efetuar-se-ão com estrita observância do princípio da licitação" (art. 126, caput).

A licitação, na técnica do novo estatuto, é o gênero de que são espécies - a concorrência, a tomada de preços e o convite (art. 127).

A concorrência é definida como "modalidade de licitação a que deve recorrer a Administração nos casos de compras, obras e serviços de vulto, em que se admite a participação de qualquer licitante através de convocação de maior amplitude" (art. $\left.127, \S 10^{\circ}\right)$.

Sem embargo da fórmula verbal usada pelo legislador, dizendo que se admite a participação de qualquer licitante à concorrência, não se trata de uma admissão ilimitada e irrestrita, pois, no art. $127, \S 2 .^{\circ}$, o Decreto-lei traça justos lindes a esse direito de admissão, estabelecendo que "nas concorrências haverá, obrigatoriamente, uma fase inicial de habilitação preliminar destinada a comprovar a plena qualificação dos interessados para realização do fornecimento ou execução da obra ou serviço programados". Essa habilitação preliminar, reza o art. 141, será julgada por comissão composta, pelo menos, de três membros.

Depois de fixar, no art. 129, o regime de publicidade das licitações, mediante notícia resumida de sua abertura, em órgão oficial e da imprensa diária, com indicação do local em que os interessados poderão obter o edital e todas as informações necessárias, o diploma em referência, no seu art. 130, determina que, entre outros requisitos, indicar-se-ão no edital, pelo menos:

I - dia, hora e local;

II - quem receberá as propostas;

III - condições de apresentação de propostas e de participação na licitação...

No art. 131, dispõe-se a respeito da documentação que poderá ser exigida, em caráter exclusivo, dos interessados para os efeitos da habilitação preliminar. 
“ $\mathrm{Na}$ habilitação às licitações, diz o artigo, exigir-se-á dos interessados, exclusivamente, documentação relativa:

I - à personalidade jurídica;

II - à capacidade técnica;

III - à idoneidade financeira.

O Decreto-lei n. 200 estatuiu, ao demais, de modo expresso, que, além das normas consubstanciadas no seu Título XII (arts. 125 a 141), ainda serão aplicáveis às licitações "as disposições complementares aprovadas em decreto" (art. 125).

\section{Exclusão por motivos de moralidade. Omissões do Decreto-lei n. 200}

19. Diante do exposto, é bem de ver a importância de que se reveste o procedimento da habilitação preliminar na concorrência, bem como a do edital em que deverão ser especificadas "as condições de participação dos interessados na licitação".

E de notar que, salvo as induções permitidas pelo art. 131 , em razão da alusão que faz à possibilidade da exigência de documentação relativa à capacidade técnica e à idoneidade financeira, nada dispõe o Decreto-lei n. 200 quanto a outros critérios, tradicionalmente válidos no direito pátrio e adotados no direito de outros países, para a admissão ou exclusão in limine dos candidatos.

Assim, por exemplo, omitiu-se qualquer referência à moralidade de pessoas físicas ou jurídicas interessadas.

A moralidade, porém, é um atributo de ordem ética, inconfundível com a capacidade técnica ou a idoneidade financeira. A pessoa pode ser tecnicamente capaz e financeiramente poderosa, sem, entretanto, inspirar a confiança que encontra seu suporte em procedimento moral incensurável.

Ter sido condenado por infração penal grave ou estar sendo processado por tal infração é matéria que entende com a moralidade da pessoa, e não com a sua capacidade técnica ou idoneidade financeira. 
"Inidôneo moralmente, na conceituação de THEMISTOCLES BRANDÃO CAVALCANTI, será o fornecedor, o negociante, o industrial, o técnico, cuja vida tenha sido atingida por fatos desabonadores de sua conduta e suas atividades, fatos esses que tenham qualquer aproximação com a natureza das relações que se propõe a manter com o Estado" ("Concorrência" in Repertório Enciclopédico do Direito Brasileiro, vol. 10, pág. 270).

"Neste caso, a medida e a natureza dos fatos ou os atos atribuidos ao concorrente ficam ao critério da administração..." (op. et loc. cit).

Pessoas naturais ou jurídicas, tecnicamente capazes e financeiramente fortes, podem incorrer na desestima moral, quando, por exemplo, agem como improbus litigatur, demandando com o só fito de causar aborrecimento e prejuizo a outrem. A litigiosidade é indicada pela doutrina como motivo de exclusão das concorrências ( $\mathrm{Cf}$. ONORATO SEPE, Contratto (dir. amm), in Enciclopédia del Diritto, IX, pág. 1.000).

Também o Supremo Tribunal Federal admitiu que, tal seja a natureza e o mérito da demanda, pode ela dar lugar ao afastamento do licitante (Cf. Ac. in Rev. de Dir. Adm., vol. 57 pág. 306). O que não se pode, evidentemente, é estabelecer, sem distinções, no edital, que qualquer demanda contra a Administração seja motivo de exclusão.

Imoral também seria o fato de qũe na licitação participasse o autor do projeto da obra, ou a firma de que faça parte, havendo, neste caso, justo motivo para excluí-los, autor e firma, da concorrência. Esse motivo de exclusão não se acha consagrado no Decreto-lei $n .^{\circ} 200$, mas consta do art. $5 .^{\circ}$ da Lei paulista de n. 10.395 , de 1970 .

Na lição de QUANCARD, ainda mesmo na ausência de texto administrativo que a imponha, justifica-se, a bem da moralidade do serviço contratante, a exclusão de "ceux qui, par leur fonction pourraient exercer une influence sur la passation du marché aussi bien que sur la régularité des opérations ultérieures de réception" (L'Administration des Marchés Publics de Travaux et de Fournitures, 1945, pág. 56).

Fatos ocorrem que, à luz de certos critérios mais ou menos rigorosos de moralidade, podem justificar a exclusão. No direito 
espanhol, por exemplo, um Regulamento de 9.2 .53 exclui das concorrências públicas as empresas em que "o Presidente, os Conselheiros, os Vogais da Comissão de Serviços e membros da administração local tenham ou adquiram mais de $10 \%$ dos títulos representativos do capital ou uma participação equivalente nos lucros, ou ocupem nessas empresas algum cargo diretor" (Cf. CARLOS GARCIA OVIEDO — ENRIQUE MARTINEZ USEROS, Derecho Administrativo, Madrid, 1968, vol. II, pág. 158).

Na Frạça são excluídas da concorrência as empresas em que a pessoa, que sofreu condenação penal, pertença ao quadro dos sócios, detendo a terça-parte ou mais do capital social (Cf. Marchés de Fournitures, de Services et de Travaux Publics" in Nouveau Rèpertoire Dalloz, vol. III, pág. 216 a 220).

Outros fatos existem que podem reclamar, no interesse do desenvolvimento e proteção da economia nacional, a exclusão de certa categoria de candidatos, como, por exemplo, a nacionalidade estrangeira ou o controle acionário, por estrangeiros, de firma nacional, fatos esses que, como já se viu, constituem motivos de exclusão de concorrentes em países europeus, como França, Bélgica e Itália.

\section{Competência implícita da Administração para excluir por motivos de ordem moral}

20. O Decreto-lei n. $.^{\circ} 200 / 67$ não cogita dos fatos acima arrolados como justo motivo de exclusão da concorrência. Poder-seia entender que, só mediante lei formal, tais razões de exclusão pudessem ser aplicadas pela Administração. Assim, porém, não é em países que também distinguem entre lei e regulamento, e onde, ainda mesmo na ausência de texto legal ou regulamentar, tais motivos de exclusão podem ser opostos pela Administração, ao interessado, desde que constantes do "caderno de encargos", do "pliego de condiciones", do "avviso d'asta", do edital da licitação. Em Portugal, consoante informa MARCELLO CAETANO, o requisito da idoneidade moral para admissão aos concursos para contratos de obras públicas e fornecimentos, foi instituido mediante, Portaria, qual seja a de $n .^{\circ} 8.716$, de 19 de maio de 1937 (Cf. op. cit., pág. 317). Antes dessa Portaria, a matéria se prestava a conflitos de interpretação entre a Administração e os Tribunais portugueses (Cf. op. et loc. cit). 
Entre nós, o Decreto-lei n. ${ }^{\circ} 200$, no seu Título XII, art. 125, estabeleceu que "as licitações para compras, obras e serviços passam a reger-se, na Administração Direta e nas autarquias, pelas normas consubstanciadas neste Título e disposições complementares aprovadas em decreto". Admitiu, portanto, o legislador, que as razões de exclusão, autorizadas pelo Decreto-lei (incapacidade técnica e inidoneidade financeira), não são de caráter exaustivo, podendo o Poder Executivo instituir, evidentemente sem discriminações injustas, outros motivos razoáveis de não-admissão às licitações.

No art. 130 determinou, de modo expresso, que no edital da licitação fossem indicadas as "condições... de participação na licitação". A palavra "condições" corresponde aí a "requisitos" a serem preenchidos pelo candidato, e não a "cláusula que subordina o efeito do ato jurídico a evento futuro e incerto" (Cód. Civ., art. 114).

O edital tem sido definido pela doutrina como a lei da concorrência. Os seus termos são vinculativos para a Administração. O edital subordina-se à lei, mas também a completa, suprindo o vazio deixado ao preenchimento da autoridade administrativa.

Escrevendo já na vigência do Decreto-lei $n .^{\circ} 200$, assim se refere CARLOS S. DE BARROS JUNIOR a esta peça do procedimento licitatório:

"Subordinado à lei e na medida em que a atende e completa, passa o edital a ser a lei da concorrência e suas cláusulas as principais fontes de direitos e obrigações da Administração e dos particulares.

"O edital deve ser objetivo e imparcial, isto é, igual para todos os licitantes, colocados em igualdade de condições. Todavia o preceito não é absoluto, admitindo-se, por exceção, preferência em favor de determinados licitantes, ou mais precisamente, de determinadas categorias de licitantes, por motivos justificados, como p.ex. vantagem para produtos nacionais, condições de maior idoneidade financeira ou técnica, da parte dos licitantes, tendo em vista a natureza da obra, etc.

“A verificação da idoneidade dos concorrentes é das mais importantes fases do processo. Apuram-se as condições de admissibilidade dos contratantes estabelecidos nos editais e pro- 
cede-se ao exame da idoneidade moral, técnica e financeira dos interessados" (Das Concorrências, in Rev. de Dir. Adm., vol. 95, pág. 15).

Também J. CRETELLA JUNIOR, em obra recente, tratando do edital da licitação, refere-se a requisitos de ordem moral que nele podem ser estabelecidos para a admissão dos interessados.

"Pelo edital, a concorrência adquire publicidade ao mesmo tempo que vincula a Administração e concorrentes. É a peça básica da concorrência, porque traça as diretrizes de todo 0 processo ulterior. Na fase que se destina a apurar a idoneidade, as autoridades examinam não só os requisitos de ordem moral, financeira etecétera, como também as condições especificadas no edital (J. CRETELLA JUNIOR, Dicionário de Direito Administrativo, 1972, pág. 64).

Uma vez que o contrato administrativo, visado pela abertura da concorrência, tem o seu fundamento no interesse coletivo, que não se define apenas em termos de valores técnicos e econômicos, senão também em consonância com padrões éticos de comportamento, não há negar que a Administração, ainda mesmo no silêncio do Decreto-lei n. ${ }^{\circ} 200$, pode estabelecer no edital da licitação aqueles requisitos de ordem moral que, a seu juízo, entender necessários para dar lugar à admissão do interessado. Assim, pode o edital afastar, desde logo, a figura do falido, do concordatário e do improbus litigatur. Pode afastar, ainda, o autor do projeto da obra e o agente administrativo cujas funções dizem respeito ao controle da execução do serviço, bem como as sociedades de que participem como detentores de maior ou menor parcela de capital. Para esse efeito, não há necessidade de lei ou de regulamento, que estabeleçam tais motivos de exclusão, pois se trata de condições pessoais dos interessados, intimamente relacionadas com a proibidade da Administração e com os valores éticos dominantes na consciência popular. ${ }^{6}$

6 - Cf. SAYAGUÉS LASO: "Las personas responsables de faltas cometidas en anteriores contratos con la administración o que hubieron realizado actos de otra indole pero tambien inconvenientes, pueden ser excluidas de las licitaciones en forma general o limitadamente. Dichas exclusiones suelen estar previstas en leyes o reglamentos. Sino lo estuvieran, pueden dictarse resoluciones individuales por razones fundadas, que excluirian al afectado de las licitaciones" (op. cit., pág. 563).

Veja-se, também, decisăo do Conselho de Estado italiano, citada por ADOLFO CUNEO: "Un consiglio communale puó stabilire speciale motivi di esclusione dalla capacità a concorrere ad asta pubblica in aggiunta a quelli stabiliti nel regolamento sulla contabilità dello Stato, purche, come quello di non aver lite vertente col Commune, siano ispirati a leggitimi motivi di pubblica utilita" Cf. Apalti Pubblici e Privati, 4.a ed., 1948, págs. 67-68, nota 2). 


\section{Exclusões por via regulamentar fundadas em razões de interesse público}

21. Tendo em vista não só o interesse direto da boa execução do serviço, senão também aspectos setoriais ou gerais da economia do país e da segurança nacional, poderá o Executivo, no uso do seu poder regulamentar, editar normas complementares a que, sob esse aspecto, deve subordinar-se a concorrência?

$\mathrm{O}$ art. 125 do Decreto-lei $n .^{\circ} 200$ dispõe que, além das normas nele previstas para reger as licitações, outras podem ser estabelecidas, em caráter complementar, quando aprovadas em decreto.

Esta última disposição, embora nada acrescente ao poder regulamentar do Executivo, que já o tem por força de Constituição (art. 81, III), entretanto indica que, no entendimento do legislador, o Decreto-lei, no tocante às licitações, não é exaustivo, mas apresenta vazios a serem preenchidos e completados pelo aplicador do diploma. É esta, aliás, a função do regulamento: prover à boa execução da lei, completando-a com disposições que não contrariem a sua letra ou o seu espírito.

"Regulamentar, diz CAIO TÁCITO, não é somente reproduzir analiticamente a lei, mas ampliá-la e completá-la, segundo o seu espírito e o seu conteúdo, sobretudo nos aspectos que a propria lei, expressa ou implicitamente, outorgue à esfera regulamentar" (As Delegações Legislativas e o Poder Regulamentar, in Rev. de Dir. Adm., vol. 34, pág. 471).

É certo que o regulamento não pode restringir direitos nem criar obrigações aos administrados. E é certo também que o respeito ao princípio constitucional de isonomia, tanto vale para o Legislativo como para o Executivo. Mas não é menos certo que, ao dispor sobre a não-admissão de particulares às concorrências púbilicas, o Poder Executivo não restringe direitos, nem impõe obrigações a quem quer que seja, porquanto, em princípio, não existe o direito subjetivo de prestar serviços ao Estado. O que existe, por sem dúvida, como princípio normativo das concorrências, é a necessidade de dispensar-se nelas, aos concorrentes, igualdade de tratamento. "Mas cuando se habla de igualdad, como acentua BIELSA, no quiere ello decir que se pueda invocar un derecho subjetivo a prestar servicios públicos, 
sino que esse derecho se atribuye al que, en igualdad de condiciones generales, acredite más idoneidad técnica, financera y moral" (Derecho Administrativo, vol. II, pág. 200).

A tese sustentada pelo Governo de Portugal de que "os concursos são estabelecidos a favor da Administração e que a sua abertura não produz quaisquer direitos para os concorrentes" (Cf. MARCELLO CAETANO, op. cit., pág. 317), está inegavelmente certa enquanto importa em negar aos particulares um direito subjetivo de admissão a todas as licitações, muito embora não se possa comungar na mesma tese, quando pretenda atribuir à Administração o poder discricionário de excluir qualquer interessado, após a publicação do edital, onde as condições de participação (conformes com a lei, o regulamento ou com as normas éticas e os princípios de interesse social informadores da teoria dos contratos administrativos), já devidamente fixadas, constituem elemento integrante da lei da concorrência, vinculando a Administração aos seus termos.

O edital, quando enumera as condições de participação, a que se refere o Decreto-lei $n .^{\circ} 200$, no seu art. 130 , item III, deve ater-se às determinações da lei, do regulamento e das regras de moralidade administrativa que implicitamente regulam todas as licitações. As condições de participação fixadas pela lei, pelo regulamento ou pela própria autoridade administrativa, quando para isso tenha competência implícita, apenas não podem ser ominosas ou caprichosamente discriminatórias, pois, se não há o direito subjetivo de prestar serviços ao Estado, não pode este recusar-se a vê-los ofertados, no procedimento licitatório, por todos os que se encontram nas condições previstas.

A nacionalidade estrangeira e a detenção da maioria do capital das sociedades por estrangeiros têm sido consideradas, no direito alienígena (França, Bélgica, Itália), como vímos, motivo legítimo de exclusão das concorrências. E de conformidade com a jurisprudência do Conselho de Estado, na França, ainda mesmo na ausência de texto expresso de lei, a exclusão por motivo de nacionalidade pode tornar-se efetiva, desde que esse motivo conste dos "cahiers des charges", que compreendem as normas administrativas, gerais e especiais, reguladoras das concorrências públicas (adjudications) (Cf. supra, item 14 e 15, e autores citados). 
A exclusão, neste caso, como acentua LAUBADĖRE (op. et loc. cit) não se inspira na necessidade da boa execução do serviço, mas em considerações de protecionismo nacional ou, diremos nós, em idéias de interesse coletivo ou de utilidade pública - idéias em que, aliás, radica o próprio instituto do contrato administrativo e que comandam, em última análise, toda a atividade do organismo estatal. Desde que, na definição de exclusões ditadas pela utilidade pública ou pelo interesse social, o dispositivo, que estabelecer a exclusão, não fira a lei ou a Constituição, não parece possível, no direito pátrio, negar ao Poder Executivo a faculdade de estatuí-la por via regulamentar.

\section{Controle acionário de empresas de serviços de engenharia - Exclusões}

22. Usando da atribuição de expedir decretos para a fiel execução das leis, prevista no art. 83 , item II, da Constituição de 67, o Poder Executivo baixou o Decreto n. 64.345 , de 10.4.69, instituindo normas para a contratação de serviços, com o objetivo de assegurar o desenvolvimento da Engenharia nacional.

\section{Lê-se no Decreto n. 64.345 :}

"Art. $10^{\circ}$ - Os órgãos da Administração Federal, inclusive as entidades da Administração Indireta, só poderão contratar a prestação de serviços de consultoria técnica e de engenharia com empresas estrangeiras, nos casos em que não houver empresa nacional devidamente capacitada e qualificada para o desempenho dos serviços a contratar."

"Parágrafo único - Consideram-se empresas nacionais, para os fins deste artigo, as pessoas jurídicas que, regularmente constituídas no país, tenham aqui sede e foro, estejam sob o controle acionário de brasileiros natos ou naturalizados residentes no país, e tenham pelo menos metade de seu corpo técnico integrado por brasileiros natos ou naturalizados."

"Art. $3 .^{\circ}$ - Para os fins deste decreto, promover-se-á, no âmbito de cada Ministério, a organização e constante atualização de um cadastro de empresas e es- 
critórios nacionais qualificados para a execução de serviços técnicos relativos às suas atividades específicas"

\section{Natureza regulamentar do Decreto n. 64.345 , de 1969}

23. Embora no preâmbulo desse Decreto não se faça referência ao Decreto-lei n. ${ }^{\circ} 200$, de 1967 , não há negar que a matéria por ele regulada (contratação de serviços de consultoria técnica e de engenharia) pertence ao âmbito dos contratos administrativos disciplinados nos arts. 125 a 144 do mesmo Decreto-lei.

A “contratação de serviços de consultoria técnica e de engenharia", embora subordinada às regras especiais complementares editadas no Decreto $n .^{\circ} 64.345 / 69$, obedecerá, necessariamente, às normas gerais, relativas a licitações para obras e serviços (concorrências, tomadas de preços, convites) estabelecidas no Decreto-lei n. ${ }^{\circ} 200 / 67$ que, entre nós, é o diploma legislativo que, basicamente, regula os contratos administrativos. A licitação só será dispensada nos casos previstos na lei.

Dessarte, quando se tratar de serviços de consultoria técnica, a licitação far-se-á mediante concorrência, desde que o vulto do serviço for igual ou superior a dez mil vezes o valor do maior salário-mínimo mensal (Decreto-lei n..$^{200}$, art. $127, \S 5 .^{\circ}$ ); e, tratando-se de obra de engenharia, caberá realizar a concorrência se o seu vulto for igual ou superior a quinze mil vezes 0 valor do maior salário-mínimo mensal (art. 127, § 6.).

A organização, em cada Ministério, de um cadastro de empresas e sscritórios qualificados para a execução dos serviços de que se trata, não só atende à exigência do art. 141 do Decreto-lei $n \cdot 200$, senão, por igual, supre a fase da prova documental destinada à "habilitação preliminar" dos interessados a que se refere o art. $127, \S 2 .^{\circ}$ O julgamento dos pretendentes ao registro cadastral há de ser feito por comissão de, pelo menos, três membros (art. 141).

Os interessados que tiverem o registro cadastral devem ficar dispensados da comprovação dos requisitos do art. 131 do Decreto-lei n. 200 (personalidade jurídica, capacidade técnica, idoneidade financeira), bastando, para tanto, apresentarem 
o "certificado de registro" (Cf. HELY LOPES MEIRELLES, Licitações e Contratos Administrativos, in Rev. de Dir. Adm. vol. 105, pág. 21-22).

Fins de proteção da engenharia nacional

24. A finalidade do Decreto $n .^{\circ} 64.345 / 69$, como se viu, é instituir normas para a contratação de serviços de consultoria técnica e de engenharia, por parte dos órgãos da administração federal, direta e indireta, para fomentar o desenvolvimento da Engenharia nacional.

Esse objetivo pretende alcançá-lo, determinando que às licitações de tais serviços só terão acesso as empresas "nacionais", isto é, as pessoas jurídicas regularmente constituídas no Brasil, que aqui tenham sede e foro, estejam sob controle acionário de brasileiros natos e naturalizados residentes no país, e tenham pelo menos metade de seu corpo técnico integrado por brasileiros natos ou naturalizados.

As pessoas jurídicas, embora "nacionais" no conceito da lei civil ou comercial, mas que não preencham os aludidos requisitos, não podem participar de contratos realizados com a Administração Pública, salvo decısão autorizatória do "Presidente da República, proferida em face de exposição justificada do Ministério interessado" (Dec. 64.345/69, art. 5. ).

\section{Contratação de serviços de engenharia por ajuste direto. Poder discricionário}

25. Nos contratos realizados, sem licitação, ou seja, mediante ajuste direto (art. 126 do Decreto-lei n. 200/67), cabe à Administração escolher, discricionariamente, a empresa que julgar capacitada para executar-lhe os serviços de consultoria técnica ou de engenharia, de que necessita. A livre escolha, por parte da Administração, é da própria natureza jurídica do ajuste direto, o qual, na definição de MARCELLO CAETANO, "consiste na formação do contrato por escolha discricionariamente feita pela autoridade competente, do concessionário, empreiteiro, fornecedor ou transportador" (op. cit., pág. 312). Nesta modalidade contratual, a Administração atua "dentro dos limites de liberdade que Ihe confere o poder discricionário" (CRETELLA JUNIOR, op. cit., vol. III pág. 106). Assim sendo, é de absoluta evidência que nos 
contratos administrativos, realizados mediante ajuste direto, nenhuma empresa de consultoria técnica ou de engenharia poderia alegar ofensa a direito subjetivo seu (de todo inexistente), por não ter sido escolhida, como co-contratante, pela Administração.

\section{Razões de argüição da inconstitucionalidade do Decreto $n .^{\circ} 64.345$}

26. Argüi-se, porém, contra o Decreto n. $64.345 / 69$, o vício de inconstitucionalidade, porquanto "nenhuma de nossas constituições, a vigente inclusive, contém qualquer restrição do direito dos estrangeiros aqui residentes (pessoais ou societários) de contratarem com os órgãos da Administração Pública Direta ou Indireta a prestação de serviços de consultoria técnica e de engenharia" (Parecer do Professor VICENTE RÁO, de 23.1.70). De tal arte, afirma-se, "o decreto federal $n .{ }^{\circ} 64.345 / 69$ é, pelos fundamentos expostos, manifestamente inconstitucional" (Parecer cit.).

A Constituição realmente não proíbe às empresas, quer nacionais, quer estrangeiras, de contratarem com os órgãos da Administração. Mas a Constituição também não proíbe à Administração Pública de escolher os seus co-contratantes, sejam eles nacionais ou estrangeiros, quer por ajuste direto, quer mediante processo licitatório.

A lei que autoriza a contratação direta de fornecimentos, obras ou serviços pela autoridade administrativa, não contraria nenhum dispositivo constitucional, pois, no Estado de Direito, tanto para a Administração, como para o particular, vale o princípio de que "ninguém será obrigado a fazer ou deixar de fazer alguma coisa senão em virtude de lei" (Const., art. 153, § 2..$^{\circ}$. Compete à lei de organização dos serviços administrativos e, no caso, tratando-se de contratos onerosos, compete à lei de direito financeiro, definir os limites dentro dos quais a Administração exercerá a faculdade de contratar e escolher o seu cocontratante. Compete à União fixar esses limites, no uso do poder que a Constituição the assegura de legislar sobre "normas gerais de gestão financeira e de direito financeiro" (art. 8., XVII, "c"). 


\section{Constitucionalidade da regulação dos contratos} administrativos no Decreto-lei $n .^{\circ} 200$, de 67

27. Na parte em que regula a realização de contratos administrativos, com ou sem licitação, de bens, serviços e obras (arts. 125 a 144), o Decreto-lei n. 200 é manifestamente constitucional, pois, tal como a Constituição vigente, já a Constituição de 1946 atribuía à União Federal, no art. 5. , XV, "b", competência para legislar sobre "direito financeiro".

Constitucional também é o art. 125 do mesmo Decreto-lei, quando dispõe que tais contratos "passam a reger-se, na Administração Direta e nas autarquias, pelas normas consubstanciadas neste Título e disposições complementares aprovadas em decreto". Ainda que o art. 125 não contivesse essa parte final, nada impediria que o Poder Executivo provesse à fiel execução do Decreto-lei n. 200 , mediante expedição de decreto que lhe facilitasse a aplicação, completando-o no atendimento a aspectos de interesse coletivo.

\section{Conceito de "empresa nacional" na técnica defeituosa do Decreto $n$. $^{\circ} 64.345$}

28. A fim de favorecer o desenvolvimento da Engenharia nacional, determinou o Decreto $n .^{\circ} 64.345 / 69$ que os serviços de consultoria técnica e de engenharia fossem contratados somente (nas licitações e nos ajustes diretos) com empresas que, no parágrafo único do art. $1 .^{\circ}$, são qualificadas como "nacionais, para os fins deste artigo.

A técnica jurídica do Decreto n. 64.345 é defeituosa, dando lugar a erros de interpretação.

Definindo como "nacionais", para os fins do art. 1. , as empresas, isto é, "as pessoas jurídicas que, regularmente constituídas no país, tenham aqui sede e foro, estejam sob controle acionário de brasileiros natos e naturalizados, residentes no país, e tenham pelo menos metade de seu corpo técnico integrado por brasileiros natos ou naturalizados", o Decreto n. 64.345 , na verdade, não legislou sobre nacionalidade de sociedades, mas, apenas, mediante a fórmula verbal adotada, excluiu dos contratos administrativos, inclusive das concorrências, todas as sociedades de consultoria técnica e de engenharia (inclusive as "nacionais"), que não preenchem aqueles requisitos. 
Equiparando empresas nacionais a estrangeiras, para efeitos de caráter administrativo, o Poder Executivo criou um problema de nomenclatura jurídica, que, no interesse de boa interpretação do texto, deve ser esclarecido.

Como acentua GENY, a linguagem se apresenta como instrumento indispensável do direito, "a tel point que, prise dans son ensemble, la technique juridique aboutisse, pour la plus grande part, à une question de terminologie" (Science et technique en droit privé positif, III). Deriva daí, na observação de SCADUTO, "per la tecnica giuridica l'importanza dei termini linguistici e della fraseologia per l'interpretazione e lo sviluppo obbiettivo della norma" (Sulla tecnica giurídica, in Riv. dir. civ., 1927, pág. 241, nota 3).

Vejamos, pois, o que significa considerar "nacionais" as empresas a que se refere o texto do parágrafo único do art. $1 .^{\circ}$ do Decreto n. 64.345 .

A nacionalidade das sociedades, como "dependência originária a uma determinada ordem jurídica" (AMILCAR DE CASTRO, Direito Internacional Privado, II, n. 140), é disciplinada, no direito pátrio, pela Lei de Introdução ao Código Civil (art. 11) e pela Lei das Sociedades por Ações (art. 60). Nos termos deste último artigo, "são nacionais as sociedades organizadas na conformidade da lei brasileira e que têm no país a sede de sua administração". É este, entre nós, o conceito legal ou legislativo de "sociedade nacional", conceito de direito privado em que o Decreto $n .^{\circ} 64.345$, de índole executiva ou regulamentar, absolumente nada inovou, nem podia inovar.

Nacionais são, efetivamente, todas as sociedades que se dedicam à prestação de serviços de consultoria técnica e de engenharia, desde que organizadas de acordo com a lei brasileira e que tenham a sede de sua administração no Brasil. Mas entre elas - nacionais que são, de conformidade com a lei brasileira -, somente serão admitidas a participar de ajustes diretos e de licitações da Administração federal as que preencherem os requisitos do parágrafo único do art. $11^{\circ}$ do Decreto n. ${ }^{\circ} 64.345 / 69$.

Ao invés de valer-se de uma equiparação suscetível de gerar perplexidade, poderia o Decreto $n .^{\circ} 64.345$ ter usado de outra fórmula verbal, para alcançar o fim visado. 
Poderia, por exemplo, dizer:

"Somente são admitidas a contratar com a Administração federal, direta e indireta, a prestação de serviços de consultoria técnica e de engenharia, as sociedades nacionais que estejam sob o controle acionário de brasileiros natos e naturalizados, residentes no país, e tenham pelo menos metade de seu corpo técnico integrado por brasileiros natos ou naturalizados. Se as sociedades nacionais não preencherem esses requisitos, só poderão contratar os serviços, de que se trata, se não houver empresa nacional, revestida daquelas características, devidamente capacitada e qualificada para prestá-los".

Aliás, é esta, realmente, a leitura que se deve fazer do parágrafo único do art. $1 . \circ$.

O Poder Executivo, neste parágrafo, não visou a legislar, no âmbito do direito privado (civil e comercial); não pretendeu atribuir ou negar, substantivamente, nacionalidade a determinadas empresas, mas, apenas, afastar dos ajustes diretos e das licitações aquelas que não fossem controladas por brasileiros natos ou naturalizados, residentes no país, e não tivessem constituído o seu corpo técnico, pelo menos, em razão da metade. por brasileiros natos ou naturalizados.

Trata-se, não de uma lei, mas de um decreto executivo, de natureza regulamentar, que outro intuito não teve senão disciplinar, na esfera administrativa, no interesse do desenvolvimento da Engenharia nacional, as contratações das obras e serviços que especifica.

\section{As discriminações do Decreto n. $64.345 \mathrm{em}$ face da Constituição}

29. Não há negar que, regulamentando, como fez, o acesso aos contratos administrativos em referência, o Poder Executivo distinguiu entre sociedades estrangeiras e nacionais e, além disso, entre sociedades nacionais controladas por brasileiros natos ou naturalizados, residentes no país, e sociedades nacionais controlados por estrangeiros, residentes ou não no Brasil, ou por brasileiros residentes fora do país.

Podia o autor do Decreto n. 64.345 fazê-lo? Era-lhe lícito proceder a essa discriminação, por um motivo que reputava de interesse público, como seja, o desenvolvimento da Engenharia 
nacional? Discriminando, como discriminou, acaso não infringiu o princípio consagrado, tanto na Constituição de 67 (art. 150), como na vigente (art. 153), in verbis:

"A Constituição assegura aos brasileiros e aos estrangeiros residentes no País a inviolabilidade dos direitos concernentes à vida, à liberdade, à segurança e à propriedade, nos termos seguintes:

\section{$\S 1 .^{\circ}$ - Todos são iguais perante a lei...".}

\section{Conceito de igualdade perante a lei}

30. Ninguém contesta que o princípio constitucional de isonomia não implica o nivelamento de todos dentro de uma igualdade absoluta. "A igualdade absoluta não existe, nem na natureza, nem na sociedade" (PAULINO JACQUES, Da Igualdade perante a Lei, pág. 233).

A igualdade jurídica, de que falam as constituições, "é a igualdade relativa, com o seu pressuposto lógico da igualdade de situações" (PAULINO JACQUES, op. cit., pág. 234).

Assim, "la garantia de igualdad no impide que se contemplen en forma distinta situaciones que se consideren diferentes" (Digesto Jurídico - Derecho Público, tomo VII, La Ley, n. ${ }^{\circ}$ 677, pág. 763).

E, por isso, também "il n'y a pas violation critiquable de l'égalité devant la loi... se le traitement discriminatoire critiqué correspond à une situation différent (l'égalité consiste à traiter inégalement les choses inégales) ou même à des nècessités publiques ou administratives reconnues par le juge" (MARCEL WALINE, Précis de Droit Administratif, Paris, 1969, pág. 339).

\section{Grupos de empresas de engenharia objeto de discriminação}

31. Lembrada, por esta forma, a doutrina corrente, não há negar que o Decreto $n .^{\circ} 64.345 / 69$ discriminou, efetivamente, entre empresas de consultoria técnica e de engenharia, no tocante ao acesso a contratos administrativos, classificando-as em dois grupos, a saber: 


\section{GRUPO}

Empresas nacionais, cujo controle acionário pertence a brasileiros natos ou naturalizados residentes no país.

\section{GRUPO}

a) Empresas nacionais, cujo controle acionário pertence a brasileiros (natos ou naturalizados) residentes fora do país;

b) Empresas nacionais, cujo controle acionário pertence a estrangeiros residentes dentro ou fora do país;

c) Empresas estrangeiras.

Tratando-se de empresas do $2 .^{\circ}$ grupo, estabeleceu o Decreto $n .^{\circ} 64.345 / 69$ que a contratação de seus serviços somente se fizesse no caso em que não houvesse empresas do $1 .^{\circ}$ grupo capacitadas a prestá-los, ou mediante autorização especial do Presidente da República.

\section{Aplicação do art. 153 da Constituição aos entes associativos. Seus limites}

32. A garantia da igualdade de tratamento, na conceituação que lhe é universalmente dada pela ciência do direito, não abrange, no texto do art. 153 da nossa Lei Fundamental, os súditos de outros Estados, nem, por extensão, as sociedades estrangeiras.

Embora o art. 153 da Constituição se refira tão-somente a pessoas físicas (Cf. PONTES DE MIRANDA, Comentários à Constituição de 69, vol. IV), é certo que, por extensão, também alcança, dentro de certos limites, as sociedades organizadas na conformidade das leis brasileiras e com sede no país, isto é, as nacionais. Mas, como assinala PONTES DE MIRANDA, se a estas "se protegem direitos com invocação da Constituição é porque, se um se lhes não permitisse, não se assegurariam aos que as compõem certos direitos, nos casos em que são constitucionais" (op. et loc. cit.). ${ }^{7}$

7 - Como adverte WOLFGANG RUENER: "O legislador só está vinculado em relaçăo aos homens (em regra os membros) que se encontram por detrás da pessoa juridica. Săo eles que devem ser tratados igualitariamente" ("Erst den hinter den juristischen Personen stehenden Menschen (in der Regel den Mitgliedern) gegenüber ist der Gesetzgeber gebunden. Sie müssen gleichbehandelt werden") - (Cf. "Zur Bedeutung und Tragweite des Art. 19 Abs. 3 des Grundgesetzes" in Archiv des offentlichen Rechts, vol. 89, ano 1964, pág. 287).

Năo impede isso o tratamento desigual de pessoas juridicas, quando fundado sobre as diferenças entre os seus membros ou sobre a diversidade do seu tipo juridico (soc. anônima, cooperativa etc.), fixado, livremente, pelo legislador (Cf. op. et loc. cit.). 
Desde que as sociedades estrangeiras não estão, para todos os efeitos, protegidas pelas garantias constitucionais, é bem de ver que um tratamento discriminatório entre elas e as sociedades nacionais, a serem favorecidas por uma razão superior, não pode implicar ofensa à Constituição.

\section{Tratamento desigual de brasileiros residentes dentro e fora do país. Exemplos}

33. A Constituição garante a igualdade de tratamento a brasileiros. Mas, diante dos interesses nacionais em jogo, o tratamento pode ser desigual, quando a situação ou condição dos brasileiros, confrontados uns com os outros, não é exatamente igual.

Afirmando que "o princípio de igualdade de tratamento prossupõe identidade de condições", o Supremo Tribunal Federal julgou legítima a distinção entre brasileiros residentes no país e brasileiros residentes fora do país, para efeito de uma tributação maior dos últimos, em contraste com os primeiros, em matéria de imposto de transmissão mortis-causa (Cf. Ac. de 24.3.1952, in D.J. de 24.3.1952, pág. 1500).

Do mesmo modo, o Tribunal de Apelação do antigo Distrito Federal teve ocasião de decidir que "não viola o princípio da igualdade de todos perante a lei a desigualdade, perante o fis$\mathrm{co}$, entre herdeiros, residentes no país e no estrangeiro" (Ac. de 19.5.1943 in Revista Forense, vol. 96, pág. 641).

Depois de acentuar que "o princípio da igualdade perante a lei foi estabelecido, conforme consta da Constituição, para vigorar somente no território nacional, não se podendo, portanto, ampliar os seus efeitos, aos cidadãos residentes no estrangeiro", reconheceu aquele Tribunal que não é idêntica a situação dos brasileiros residentes no país e a dos residentes fora dele, sendo lícita a discriminação entre eles para efeitos fiscais. E, em seu voto, assinala o Des. JOSÉ DUARTE que, distinguindo entre uns e outros, "a lei quis considerar a especial circunstância do nacional que vive noutro país, sem participar da vida de sua pátria, alheado dos seus problemas, das suas necessidades" (Cf, Revista Forense, vol. 96, pág. 646).

A distinção entre brasileiros, residentes dentro e fora do país, pode ser verificada, ainda, em matéria fiscal, na vigente legislação do imposto de renda. 
Nos termos do art. 292 do Regulamento (RIR) em vigor, estão sujeitos ao desconto do imposto na fonte - à razão de $25 \%$ - todos os rendimentos tributáveis, quando percebidos pelas pessoas físicas residentes no estrangeiro, estando, ao revés, as aqui residentes sujeitas à incidência de uma taxa menor.

O RIR distingue, ainda, para os efeitos de tributação agravada, entre pessoas físicas (inclusive brasileiros) residentes no exterior, quando os lucros por elas auferidos o são "em empresas cujos capitais sejam aplicados em atividades econômicas de menor interesse para a economia nacional, tendo em conta inclusive sua localização, definidas em decreto do Poder - Executivo". Tratando-se de empresas de menor interesse, o sócio, residente no exterior, pagará o imposto sobre o lucro ou dividendo com acréscimo de $20 \%$.

Não parece, assim, diante dessa orientação dos nossos tribunais e da nossa legislação, que o fato de discriminar o Decreto $n .^{\circ} 64.345$ entre empresas nacionais, cujo controle acionário é exercido por brasileiros residentes fora do pais, e empresas nacionais, controladas por brasileiros aqui residentes, para efeitos de contratação de serviços técnicos e de engenharia, possa importar em injusta desigualdade de tratamento.

A distinção entre as empresas é feita em função da diferença de situação (ambiência de vida, menor identificação com os problemas nacionais) dos membros das aludidas sociedades - uns brasileiros aqui residentes e outros brasileiros que aqui não residem, embora controlando, uns, em contato direto no país, e outros, à distância, do exterior, a vida e o destino das respectivas empresas.

Entendeu o autor do Decreto que seriam mais úteis, ao desenvolvimento da Engenharia nacional, as contratações de empresas controladas por brasileiros aqui residentes, do que as sob controle de brasileiros residentes fora do país.

Não se trata de discriminação arbitrária, mas informada em uma finalidade de conveniência coletiva, que tem por si uma presunção de autenticidade da avaliação dos interesses nacionais em jogo. 


\section{Desigualdade de tratamento de estrangeiros residentes no exterior não ofende a Constituição}

34. Achando-se a sociedade controlada por estrangeiros residentes no exterior, justifica-se a distinção, até com maior intensidade, do que no caso de brasileiros ali residentes. O controle acionário exercido por estrangeiros, fora do país, não é positivamente igual ao controle de brasileiros, que aqui atuam integrados na vida econômica e social da Nação.

\section{Distinção entre brasileiros e estrangeiros residentes no país, em lei ordinária. Possibilidade jurídica}

35. O art. 153 da Constituição vigente, à semelhança de Constituições anteriores, refere-se a "brasileiros e estrangeiros residentes no país".

No art. $9 .^{\circ}$, item I, a Lei Magna proíbe à União, aos Estados, ao Distrito Federal e aos Municípios criarem distinções "entre brasileiros".

Na Constituição de 1934, essa proibição constava do art. 17 , item I, mas com a particularidade de restringir-se a "brasileiros natos". Referindo-se a esse dispositivo, escreve PAULINO JACQUES: "De modo especial, convém salientar a inovação que proíbe "distinguir entre brasileiros natos", que bem traduz o nacionalismo sadio que informa a Constituição de 1934, permitindo a distinção entre brasileiros natos e naturalizados, para efeitos civis, políticos e econômicos" (Curso de Direito Constitucional, 6a. ed. 1970 , pág. 146; no mesmo sentido PONTES DE MIRANDA, Comentários à Constituição de 1967, vol. IV, pág. 705).

A Constituição retificada pela Emenda constitucional $n \cdot{ }^{\circ} 1$ somente veda a distinção "entre brasileiros" (art. $9 .^{\circ}$, item 9), admitindo, implicitamente, maior área de discriminação entre "brasileiros" e "estrangeiros residentes no país". A norma do art. $9 .^{\circ}$, item I, se não contradiz 0 art. 13 da Lei Magna, entretanto amortece, em relação aos "estrangeiros residentes no país", a força e intensidade da proteção que lhes assegura o art. 153.

As garantias constitucionais também são válidas em relação aos estrangeiros residentes no país, mas cum grano salis, 
justificando-se a discriminação se não for arbitrária, como quando reclamada pelo interesse nacional.

Parece-nos que é esta a interpretação que resulta do confronto do art. 9, item I, e art. 153 da Constituição, que, assim, proporciona, no seu próprio texto, elemento de exegese que justifica distinções, evidentemente não ominosas, entre nacionais e estrangeiros aqui residentes.

Aliás, o constituinte não podia desconhecer os dados da sociologia, que aponta as diferenças, intrínsecas, naturais, as diferenças de personalidade, entre nacionais e súditos de outros Estados. Como adverte AKZIN "a circunstância de ter nascido em país pertencente a uma comunhão étnica e a de ter sido educado na mesma ambiência étnica, são fatos que se podem denominar históricos na vida do indivíduo: como verdadeiros fatos históricos, deixam traços indeléveis na personalidade inteira - física, intelectual e moral do individuo considerado..." (La sociologie de la nationalité, pg. 16, apud ESPINOLA e ESPINOLA FILHO, Tratado de Direito Civil Brasileiro, vol. V, pág. 84 , nota f).

Tendo em vista esse aspecto que a sociologia constata, as Constituições, no seu próprio texto, distinguem, para certos efeitos, entre nacionais e estrangeiros, estes residentes ou não no país. Mas a distinção também se faz na legislação comum, quando existem razões que a justificam.

No direito pátrio, são numerosos os diplomas da legislação ordinária em que se discrimina entre brasileiros e estrangeiros residentes no país. ${ }^{8}$

Assim, por exemplo, embora a Constituição de 1891 não cogitasse do assunto, o Decreto $n .^{\circ}-20.291$, de 12 de agosto de 1931, conhecido pelo nome de "lei dos dois terços", estabeleceu, em favor dos brasileiros natos, preferências, na razão de $2 / 3$, ao trabalho na indústria e comércio.

\footnotetext{
8 - Há casos em que a lei discrimina năo só entre brasileiros residentes dentro e fora do país ou entre brasileiros e estrangeiros aqui residentes, senăo também, até mesmo, entre brasileiros natos residentes no território nacional, quando há motivo razóavel para distinguir. Veja-se, a propósito, PAULINO JACQUES, Da igualdade perante a lei, págs. 172 e 198, e TRIBUNAL PLENO do T.J.S.P., na Revista dos Tribunais, vol. 273 , pág. 434 , onde se trata de discriminações entre brasileiros residentes no país, consideradas năo infringentes do princípio de isonomia consagrado na Constituição.
} 
O Decreto-lei n. ${ }^{\circ} 1.400$, de 3.6.1939, estatuiu a condição de brasileiro nato ou naturalizado para a obtenção da carteira de motorista profissional, fundamentando a medida no fato de que "na atual situação de emprego generalizado da motorização, importa à segurança nacional, dispor do maior número possível de motoristas profissionais brasileiros, com que se possa contar em caso de guerra".

Promulgado na vigência da Carta de 37 , o Código de Pesca (Decreto $n .704$, de 19.10.1938), mesmo na ausência de texto constitucional que o determinasse, reservou aos "brasileiros", com exclusão, pois, dos "estrangeiros residentes no país", "o direito de exercer e explorar profissionalmente a pesca e indústrias correlatas".

Registrando a existência desses diplomas da legislação ordinária, ESPINOLA e ESPINOLA FILHO o fazem sem aludir, nem de leve, a qualquer problema de inconstitucionalidade (Trat. VI, pág. 406).

O Código de Contabilidade reserva aos proponentes brasileiros, em igualdade de condições, o direito de preferência em todos os fornecimentos a serem feitos às repartiçóes públicas federais (art. 742). E essa preferência que, em última análise, importa em discriminar entre brasileiros e estrangeiros aqui residentes, foi considerada legítima, sobre o fundamento de basear-se em interesse público e preponderante (Cf. Sentença do Dr. Raimundo Ferreira de Macedo, in Revista de Direito Administrativo, vol. 15, pág. 220).

Não cabe, portanto, o argumento de que a distinção entre brasileiros e estrangeiros; residentes no país, somente é admissível quando a Carta Magna expressamente o autorizar. A desigualdade de tratamento - (é o que se colhe da tradição do nosso direito e do próprio conceito jurídico de igualdade) - é sempre possível quando existe um motivo razoável para o tratamento desigual.

Não se pode, no caso, questionar na esfera administrativa a razoabilidade da providência estabelecida pelo Decreto ..... n. $64.345 / 69$, que tem a seu favor a presunção de que, para 
editá-la, o Poder Executivo analisou todas as repercussões que sua execução teria no desenvolvimento da Engenharia brasileira 9 .

Distinguindo entre sociedades de consultoria técnica e de engenharia, controladas por brasileiros, e sociedades da mesma espécie, controladas por estrangeiros residentes no país, para efeito de acesso aos contratos administrativos da União, o Decreto $n .^{\circ} 64.345$ não o fez de modo arbitrário, mas indicando, na sua ementa, que para tanto se baseou no interesse do desenvolvimento da Engenharia nacional.

A distinção que o Decreto fez entre sociedades nacionais, controladas por brasileiros, e sociedades, também nacionais, sob o controle de estrangeiros, residentes no Brasil, não pode, conseguintemente, ser arguida de inconstitucional, por violação do princípio de isonomia, uma vez que não é idêntica a situação dos individuos que exercem o respectivo controle - uns estrangeiros, aqui residentes, em vias de maior ou menor adaptação às condições do país, outros brasileiros, já marcados, pelo nascimento ou pelo abandono voluntário da cidadania de origem, com um grau ótimo ou sumamente elevado de integração na vida da, Nação.

\section{Desigualdade de tratamento de estrangeiros no direito francês}

36. A discriminação, em dados casos, entre nacionais e estrangeiros, residentes no país, ocorre, não só no Brasil, mas em

9 - Analisando diversas decisöes proferidas por tribunais, no ambito internacional, JEAN CHARPENTIER chega à seguinte conclusăo:

"Toute inégalité de traitment entre nationaux et étranger n'est donc pas discriminatoire; n'est discriminatoire que le traitment imposé à l'étranger parce qu'il est étranger...

Assim, "pour qu'une mesure de nationalisation discriminatoire soit illicite, il ne suffit pas qu'elle défavorise un étranger à raison de sa nationalité, il faut en outre qu'elle soit inspirée par un sentiment de malveillance à l'égard de cette nationalité - discrimination dolosive".

E, dessarte, "on coiçoit la discrimination... comme une mesure inspirée par un sentiment de malveillance ù l'égard de la nationalité de l'entrepreneur étranger au lieu d'étre imposée par les nécessités de la politique économique" (De la non discrimination dans les investissements, in Annuaire française de Droit International, 1963, Paris, Centre National de la Recherche scientifique 1964 , págs. 47,49 e 50 ).

Acentua, ainda, CHARPENTIER que, em favor da medida discriminatória, milita uma natural presunçăo de legitimidade, cabendo, por isso, ao estrangeiro provar a ilicitude da discriminaçăo, inclusive que o Poder, que a estabeleceu, tenha agido com a intençăo de prejudicar. "En réalité, il faut, conformérent au principe général de la bonne foi, présumer qu'une mesure de nationalisation est régulière, même si elle ne frappe que des étrangers: c'est donc le demandeur qui aura la charge de la preuve de la discrimination"; sendo certo que "I'intention de nuire est nécessaire... pour vicier l'opération" (op. cit., pág. 51). 
Estados cuja constituição também afirma o princípio da igualdade de todos os homens (inclusive, pois, dos estrangeiros) perante a lei.

Na França, o preâmbulo da Constituição de 1946 reafirmou "solenemente os Direitos e as Liberdades do Homem e do Cidadão consagrados pela Declaração de Direitos de 1789 e os princípios fundamentais reconhecidos pelas leis da República".

A Constituição de 1958 proclama "o apego do povo francês aos Direitos do Homem, definidos pela Declaração de 1789, confirmada e completada pelo preâmbulo da Constituição de 1946".

A Constituição de 1875 se absteve de invocar expressamente os princípios das Declarações. Mas como acentua MARCEL SIBERT, "la Constitution de 1875 les présuppose" (La Constitution de la France, 1945, pág. 27). "Aussi bien, depuis longtemps, les principes des Déclarations avaient ils acquis la valeur d'un dogme" (Ibid., pág. 68). Entre esses dogmas estava "L'Égalité devant la loi" (loc. cit).

Após a Constituição de 1958, como mostra JACQUES GEORGEL, o Conselho de Estado, na França, tem feito expressa referência à Declaração dos Direitos do Homem de 1789. Analisando esses pronunciamentos, conclui esse escritor que "sous quelque aspect qu'on envisage le Préambule, on se trouve conduit à lui attribuer une valeur de règle constitutionelle et non de simple référence sentimentale. La France veut demeurer le pays des Droits de l'Homme" (Aspects du Préambule de La Constitution du 4 Octobre 1958, in Revue du Droit Public et de la Science Politique jan. fev. 1960, pág. 101).

Sem embargo, porém, de inscrever-se a igualdade de todos perante a lei entre os princípios constitucionais do Estado francês, numerosos são os casos em que, na França, a lei, o regulamento e os "cahiers de charges" discriminam entre nacionais e estrangeiros, residentes no país.

"Na França libérrima, escreve JOSÉ DUARTE, a lei das locações de prédios houvera em consideração a nacionalidade do proprietário e da locatário (lei de 1 de abril de 1926, de 30 de julho de 1926 e 22 de abril de 1927). Isto sem embargo dos tratados de comércio, assegurando a igualdade de tratamento aos estrangeiros, que eram assinados e celebrados" (Rev. Forense, vol. 96, pág. 646). 
O Decreto de 17 de junho de 1938 proibiu que os estrangeiros exercessem na França uma atividade comercial ou industrial se, no país de origem, os franceses não são admitidos a exercer a mesma profissão.

O estrangeiro, mesmo residente, não pode ser diretor de cooperativa agrícola (Ord. de 12.10.1945), nem dirigir um grêmio ou cassino, ou ser empregado numa sala de jogo (Lei de 15.6.1907).

Os trabalhos ambulantes só podem ser exercidos pelo estrangeiro após 5 anos de residência (Lei de 6.7.1912; Decreto - de 30.10 .1935 ).

A lei de 26 de novembro de 1873 subordinou a proteção ao nome comercial, para o estrangeiro, à reciprocidade diplomática ou legislativa (Cf. H. BATTIFOL, Traité Élémentaire de Droit International Privé, 2a. ed, 1955, pág. 208).

Como já se viu, mesmo na ausência de texto expresso, desde que a cláusula de exclusão conste do "cahier des charges", os estrangeiros não têm acesso às concorrências públicas.

Inobstante, pois, o princípio de isonomia, proclamado pela jurisprudência, a discriminação entre estrangeiros e nacionais, com vistas à proteção econômica e social dos últimos, é assaz freqüente no direito francês.

\section{Discriminação entre nacionais e estrangeiros no direito norte-americano}

37. A décima quarta emenda da Constituição dos Estados Unidos dispõe que "nor shall any State deprive any person of life, liberty, or property, without due process of law; nor deny to any person within its jurisdiction the equal protection of the law".

Trata-se, na lição de STORY, da enunciação, sob outra roupagem, do princípio da igualdade de todos perante a lei. "It is a formal declaration of the great principle that has been justly said to pervade and animate of government, that all are equal before the law" (Commentaries on the Constitution of the United States, Boston, 1873, vol. II, § 1960). 
Referindo-se à 14a. emenda, acentua T.H. HEALY: "Il faut remarquer que cette clause de la Constitution ne se limite pas aux nationaux, mais s'applique à toutes personnes" (La Condition juridique de l'étranger spécialement aux États-Unis, in Recueil des Cours, t. 27, ano 1929, pág. 447).

Apesar disso, como mostra HEALY, no artigo citado, nos Estados Unidos, "comme dans tous les pays, il existe certaines différences entre le droit et l'obligation des étrangers et ceux des nationaux" (Cf. op. cit., pág. 447).

Numerosas são as restrições impostas aos estrangeiros nos diversos Estados da Federação norte-americana, embora sofrendo modificações através dos tempos.

De começo, os estrangeiros não gozavam do direito de testar, não podendo, em conseqüência, legar sua propriedade nem mesmo a um cidadão estadunidense. Quando um estrangeiro falecia intestado, a sua propriedade passava ao Estado.

No Distrito de Columbia, que se encontra diretamente sob a jurisdição do governo federal, não havia, de início, distinção entre nacionais e estrangeiros no que respeita à aquisição de terras. As leis de 1830 e 1836 tratavam estrangeiros e nacionais em pé de igualdade. "Plus tard, la législation ne concédait des droits qu'aux nationaux ou aux individus qui avaient déclaré leur intention d'acquerir la nationalité américaine" (HEALY, op. cit., pág. 449).

Em decisão de 1923, proferida no caso Terrace vs. Thompson, a Suprema Corte proclamou que "la législation d'État s'appliquant également et uniformément à tous les étrangers en les privant du droit de posséder des biens fonciers, ne constitue pas une privation arbitraire de la liberté ni de. la proprieté, et n'est pas en contravention avec les dispositions de la Constitution fédérale" (HEALY, op. cit. pág. 460).

Decidiu, ainda, no mesmo caso, a Suprema Corte que "I'État peut déterminer discrétionnairement sa propre politique dans les affaires publiques, et les mesures qu'il juge nécessaires pour sa protection et le maintien de la sécurité, de la paix et du bon ordre de son peuple. La clause d'égale protection n'interdit pas à la loi de l'État toute distinction entre nationaux et étrangers" (HEALY, op. cit., pág. 462). 
No Estado de Nebraska "os estrangeiros não podem constituir maioria num conselho de administração, nem ter a maioria das ações de uma associação organizada para possuir ou que possui bens imobiliários, e ditas associações não podem eleger estrangeiros como membros executivos ou diretores" (ibid., pág. 466).

"Un certain nombre d'États, parmi lesquels se trouve la Californie, ont édicté une législation spéciale interdisant aux "corporations" dont les actionaires sont étrangers, d'acquerir et de posséder de biens fonciers. Ces lois établissent en général le pourcentage d'actionaires étrangers qui est autorisè, et certaines établissent une distinction entre les étrangers admissibles à la naturalisation et ceux qui ne le sont pas" (ib., pág. 469).

No caso Heim vs. McCall, a Suprema Corte dos Estados Unidos aprovou a lei de um Estado que proibia o emprego de estrangeiros como trabalhadores em obras públicas do Estado. A Corte declarou que era esta uma restrição razoável, uma vez que as obras públicas pertenciam ao Estado e aos seus cidadãos, e que era justo excluir os estrangeiros de tais obras" (Cf. HEALY, op. cit., pág. 474).

Além dessas restrições, aqui dadas em caráter exemplificativo, outras existem, ou existiram, quanto ao direito dos estrangeiros na grande nação norte-americana.

Também ali o princípio de isonomia, inscrito na Constituição, não impede se façam distinções entre nacionais e estrangeiros residentes no país, quando a discriminação se funda em motivo razoável, como seja, num interesse público relevante 10 .

\section{Constitucionalidade do Decreto $n .^{\circ} 64.345$}

38. Distinguindo, por um lado, entre sociedades estrangeiras e nacionais, e, por outro, entre sociedades nacionais (regularmente organizadas e sediadas no Brasil), umas controladas por brasileiros residentes no país, e, outras, por estrangeiros ou brasileiros, residentes no exterior, o autor do Decreto $n .^{\circ} 64.345 / 69$

10 - Năo só na França e nos Estados Unidos ocorrem discriminações entre nacionais e estrangeiros. Trata-se de fenômeno assaz freqüênte e difundido.

"Dans certains Etats comme au Danemark, diz CHARPENTIER, où les lois ne distinguent entre nationaux et étrangers, aucun permis d'explotations de ressources hydrauliques n'a, en fait, jamais été accordé à des étrangers. Or, ce pouvoir discrétionaire ne joune pas seulement à propos de ressources naturelles...

"On peut enfin relever que de nombreux pays exigent une participation majoritaire de capitaux nationaux dans la plupart des entreprises économiques (op. cit., pág. 43). 
o fez tendo em vista o interesse do desenvolvimento da tecnologia brasileira, no setor da Engenharia nacional.

O princípio da igualdade de todos perante o Legislativo, o Executivo e o Judiciário não impede, como se viu, tanto no Brasil, como noutros Estados em que o princípio vigora em toda a sua plenitude conceitual, se façam distinções entre nacionais e estrangeiros, ou entre sociedades controladas por nacionais ou estrangeiros, quando existe motivo razoável.

Nos ajustes diretos da Administração, a escolha do cocontratante está dentro dos limites de sua discricionariedade. Nenhuma empresa individual ou coletiva pode alegar ofensa a direito subjetivo seu, por não ter sido eleita para o contrato administrativo.

No caso de licitação, o edital é a' lei do procedimento licitatório e do contrato a concluir. Fixadas, no edital, as condições de participação na licitação (art. 130, III, do Decreto - lei .. n. 200/67), só terão acesso a ela os que preencherem os requisitos estabelecidos, desde, evidentemente, que não envolvam discriminações personalistas, arbitrárias e odiosas ${ }^{11}$.

O edital pode e deve estabelecer motivos de exclusão, não só com base em razões técnicas e financeiras, senão também no interesse da preservação da moralidade da Administração, ainda que a lei não se refira explicitamente a esses aspectos.

Havendo razões de peso, fundadas na salvaguarda da segurança ou do desenvolvimento tecnológico, econômico e social do país, nada obsta que o Poder Executivo, incumbido de aplicar a lei das licitações no âmbito administrativo, a complemente por via regulamentar, determinando, com base no interesse nacional, as hipóteses de exclusão a serem especificadas no edital da concorrência.

A constitucionalidade, de par com a legalidade do Decreto n. ${ }^{\circ} 64.345 / 69$, parece inquestionável, não cabendo às empresas, excluídas das contratações administrativas da União, o direito de participar de suas licitações e dos seus contratos, de que, por motivo relevante, foram afastadas.

11 - O texto do art. 130, item III, Justifica o entendimento que à matéria fol dada, em tese, pelo Ministro DJALMA DA CUNHA MELO: as condiçōes do edital da oferta, nos casos de connorrêncla Código de Contabilidade Pública. É a liçăo dos tratadistas. RECAREDO FERNANDES VELASCO, por exemplo, ressalta que o pliego de condiciones fica ao nuto do Administrador... Só distinçőes ominosas, distinçŏes vedadas por lei, possibilitam reclamo do pretendente à concorrência". (Rev. Dir. Adm., vol. 37, pág. 300). 
